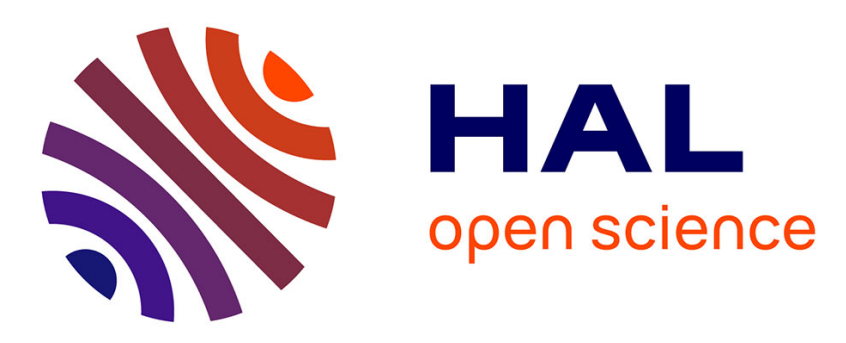

\title{
Analysis of polymorphisms in the insulin-like growth factor 1 receptor (IGF1R) gene from Japanese quail selected for body weight
}

\author{
H.H. Moe, T Shimogiri, W. Kamohiraguma, H. Isobe, K. Kawabe, S. \\ Okamoto, Francis F. Minvielle, Y. Maeda
}

\section{To cite this version:}

H.H. Moe, T Shimogiri, W. Kamohiraguma, H. Isobe, K. Kawabe, et al.. Analysis of polymorphisms in the insulin-like growth factor 1 receptor (IGF1R) gene from Japanese quail selected for body weight. Animal Genetics, 2007, 38, pp.659-661. hal-02656189

\section{HAL Id: hal-02656189 \\ https://hal.inrae.fr/hal-02656189}

Submitted on 29 May 2020

HAL is a multi-disciplinary open access archive for the deposit and dissemination of scientific research documents, whether they are published or not. The documents may come from teaching and research institutions in France or abroad, or from public or private research centers.
L'archive ouverte pluridisciplinaire HAL, est destinée au dépôt et à la diffusion de documents scientifiques de niveau recherche, publiés ou non, émanant des établissements d'enseignement et de recherche français ou étrangers, des laboratoires publics ou privés. 


\title{
Analysis of polymorphisms in the insulin-like growth factor 1 receptor (IGF1R) gene from Japanese quail selected for body weight
}

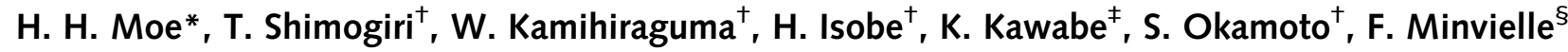 \\ and Y. Maeda ${ }^{\dagger}$
}

*The United Graduate School of Agricultural Sciences, Kagoshima University, Kagoshima 890-0065, Japan. 'Faculty of Agriculture, Kagoshima University, Kagoshima 890-0065, Japan. ${ }^{\ddagger}$ Frontier Science Research Center, Kagoshima University, Kagoshima 890-0065, Japan. §UMR1236 INRA/INA-PG Génétique et Diversité Animales, Jouy en Josas 78350, France

\section{Summary}

\begin{abstract}
Insulin-like growth factor 1 receptor (IGF1R) is essential for the signalling of growth. In this study, we performed single nucleotide polymorphism (SNP) detection in the Japanese quail IGF1R coding region and an association study between SNPs and body weight in two lines (SS and LL) selected for large and small body weight. Of 21 SNPs obtained, a SNP at position AB292766:c.2293G>A led to the replacement of a valine with an isoleucine (V765I). The two lines were fixed for alternate alleles, with allele encoding valine fixed in the LL line. A significant effect of the SNP genotype was found on 10 -week body weight $(P<0.01)$ and on 4 - to 10-week and 6- to 10 -week average daily gain $(P<0.05)$ in the $\mathrm{F}_{2}$ family obtained from lines LL and SS. In six populations maintained in Japan or France, the frequency of allele encoding valine was higher than the allele encoding isoleucine.
\end{abstract}

Keywords growth, insulin-like growth factor 1 receptor, Japanese quail, single nucleotide polymorphism.

Insulin-like growth factor 1 receptor (IGF1R), expressed in many developing tissues, is a tyrosine kinase with a key role in normal growth and development. In birds, the biological actions of two growth factors (IGF1 and IGF2) are mediated by the IGF1R with different affinities (Yang et al. 1991). Recently, a single nucleotide polymorphism (SNP) in the IGF1 gene was associated with several economically important traits in chicken (Amills et al. 2003; Bennett et al. 2006). However, the role of the IGF1R gene in bird growth is unclear. Correspondingly, the objectives of the present work were to obtain a complete coding sequence of the Japanese quail IGF1R, to find SNPs and to carry out the first investigation of the association between the SNPs and growth traits.

Japanese quail from different origins were used: (i) LL and SS lines developed by divergent selection on body weight and their control random-bred lines RR (Okamoto et al. 1989); (ii) a random-bred line of the KU population maintained at Kagoshima University; (iii) the French heavy line K (Minvielle et al. 1999); (iv) the medium-size INRA lines AA and EE selected on early egg production (Minvielle

Address for correspondence

T. Shimogiri, Faculty of Agriculture, Kagoshima University, Kagoshima 890-0065, Japan.

E-mail: simogiri@agri.kagoshima-u.ac.jp

Accepted for publication 17 July 2007 et al. 2000); (v) two other commercial lines (the egg laying line $\mathrm{A}$ and the broiler line $\mathrm{C}$ ); and (vi) an $\mathrm{F}_{2}$ family constructed from intercrossing lines LL and SS for the analysis of the association between SNPs and growth traits.

Six primer sets designed from the chicken IGF1R cDNA sequence (AJ223164) were used for determination of the Japanese quail IGF1R coding region (Table S1). The nucleotide sequence data have been submitted to DDBJ as accession numbers AB292766 and AB292767. The IGF1R coding region was 4092 bp in length, encoding for a 1363 amino acid sequence, and the deduced amino acid sequences had $99.4 \%$ identity to that of chicken (CAA11144).

Sequence comparison of the IGF1R coding region between LL and SS birds specified the existence of 21 SNPs. Of the 21 SNPs, only one led to the replacement of an amino acid: a G-to-A SNP at position 2293 (of accession numbers AB292766 and AB292767) led to the substitution of a valine by an isoleucine (V765I). Detection of this SNP by PCR-RFLP showed that the c.2293A allele appeared to be fixed in line SS ( 67 birds), and lost in lines LL (20 birds) and RR (28 birds). The frequency of the c.2293A allele ranged from 0.18 to 0.31 in six populations maintained in Japan or France (Table 1). A chi-squared test showed the observed genotypic values were not statistically different from the expected values based on the Hardy-Weinberg equilibrium. 
Table 1 Genotypic and allelic frequencies of the SNP in the IGF1R gene in Japanese quail populations of various origins and body weights.

\begin{tabular}{|c|c|c|c|c|c|c|c|c|}
\hline \multirow[b]{2}{*}{ Line (mean body weight) } & \multirow[b]{2}{*}{ No. of birds } & \multicolumn{3}{|l|}{ Genotype } & \multicolumn{2}{|l|}{ Allele } & \multirow[b]{2}{*}{$\chi^{2}$} & \multirow[b]{2}{*}{$P$-value } \\
\hline & & c. $2293 A A$ & c. $2293 A G$ & c.2293GG & c. $2293 \mathrm{~A}$ & c. $2293 G$ & & \\
\hline \multicolumn{9}{|l|}{ Kagoshima } \\
\hline KU 1st [109.2 (male), 135.3 (female)] & 106 & 4 & 30 & 72 & 0.18 & 0.82 & 0.15 & $0.9<P<0.95$ \\
\hline KU 2nd (no data) & 67 & 1 & 25 & 41 & 0.2 & 0.8 & 1.71 & $0.25<P<0.5$ \\
\hline KU 3rd (no data) & 294 & 3 & 97 & 194 & 0.18 & 0.82 & 5.91 & $0.05<P<0.1$ \\
\hline \multicolumn{9}{|l|}{ France } \\
\hline AA (165.3) & 20 & 0 & 8 & 12 & 0.2 & 0.8 & 1.25 & $0.5<P<0.75$ \\
\hline $\mathrm{EE}(197.7)$ & 19 & 1 & 9 & 9 & 0.29 & 0.71 & 0.44 & $0.75<P<0.9$ \\
\hline$A(178.2)$ & 21 & 3 & 7 & 11 & 0.31 & 0.69 & 1.02 & $0.5<P<0.75$ \\
\hline K (372.9) & 21 & 1 & 6 & 14 & 0.19 & 0.81 & 0.11 & $0.9<P<0.95$ \\
\hline$C(286)$ & 21 & 1 & 9 & 11 & 0.26 & 0.74 & 0.25 & $0.75<P<0.9$ \\
\hline
\end{tabular}

$\chi^{2}$ : the chi-squared value.

$P$ : Hardy-Weinberg equilibrium test.

$\mathrm{KU}$ 1st, KU 2nd and KU 3rd: a random-bred population KU maintained at Kagoshima University.

An inverse distribution of allelic frequencies of this polymorphism between LL and SS lines suggested that the IGF1R SNP might be associated with the body weight in these lines. Body weight, average daily gain (ADG) and shank length of the $\mathrm{F}_{2}$ quail were measured at 4,6 and 10 weeks of age. The Kolmogorov-Smirnov test showed that the distribution of the data was not different from that of a sample drawn from a normal distribution. All association analyses between SNPs and traits were performed by using the GLM procedure (general linear model) of the sas library of programs.

The c.2293GG and c.2293AG males were significantly heavier than the c.2293AA males, and the c.2293GG females were significantly heavier than the c.2293AA females, with intermediate weights for the c.2293AG female heterozygotes at 10 weeks of age (Table 2). The corresponding GLM results for $\mathrm{F}_{2}$ body weights at 4,6 and 10 weeks of age showed significant differences due to the sex $(P<0.001)$ and the SNP genotype $(P<0.01)$ on 10 -week body weight. For ADG, differences $(P<0.05)$ among genotypes were also observed after 6 weeks of age (Table 3). These results suggest that the c. 2293G allele had a positive effect on adult body weight in the $\mathrm{F}_{2}$ population. Of course, as shown by Zhao et al. (2003), the observed association of body weight with IGF1R might be also affected by some population-wide linkage disequilibrium of IGF1R with the true causative gene, because of the extensive between-line linkage disequilibrium expected in an $\mathrm{F}_{2}$. Concerning shank length, no significant differences were found among the three genotypes (data not shown).

In a first attempt at extending the result obtained in the $\mathrm{F}_{2}$, the associations between the genotype and body weight and between the genotype and shank length were studied in the other Japanese and French lines segregating for the c. $2293 \mathrm{G}>\mathrm{A}$ polymorphism, but no significant differences could be found between the genotypes for these two traits (data not shown).

The IGF1R SNP may be significantly linked to genes for body weight and growth, and/or random genetic drift may have caused the divergence at this SNP between the two

Table 2 Body weight (BW) (g) and ADG (g/day) according to the SNP genotype of the $F_{2}$ generation from divergent lines SS and LL at 4, 6 and 10 weeks of age (mean \pm SD).

\begin{tabular}{|c|c|c|c|c|c|c|c|}
\hline \multirow[b]{3}{*}{ Traits } & \multirow{3}{*}{$\begin{array}{l}\text { Age } \\
\text { (weeks) }\end{array}$} & \multicolumn{6}{|l|}{ Genotype } \\
\hline & & \multicolumn{3}{|l|}{ Male } & \multicolumn{3}{|l|}{ Female } \\
\hline & & c. $2293 \mathrm{AA}(n=18)$ & c. $2293 \mathrm{AG}(n=32)$ & c.2293GG $(n=12)$ & c. $2293 \mathrm{AA}(n=13)$ & c.2293AG $(n=34)$ & c.2293GG $(n=15)$ \\
\hline \multirow[t]{3}{*}{ BW } & 4 & $76.93 \pm 8.85$ & $79.77 \pm 11.72$ & $78.45 \pm 12.54$ & $76.25 \pm 8.18$ & $76.66 \pm 11.65$ & $78.24 \pm 11.29$ \\
\hline & 6 & $102.93 \pm 6.71$ & $105.74 \pm 11.74$ & $107.13 \pm 11.53$ & $108.28 \pm 17$ & $109.48 \pm 16.68$ & $112.37 \pm 15.07$ \\
\hline & 10 & $106.48 \pm 10.3^{a}$ & $113.44 \pm 8.14^{b}$ & $115.62 \pm 10.19^{b}$ & $130.73 \pm 17.88^{\mathrm{a}}$ & $136.14 \pm 17.19^{\mathrm{ab}}$ & $145.49 \pm 20.77^{b}$ \\
\hline \multirow[t]{3}{*}{ ADG } & $4-6$ & $1.86 \pm 0.52$ & $1.85 \pm 0.55$ & $2.05 \pm 0.53$ & $2.29 \pm 0.87$ & $2.34 \pm 0.74$ & $2.44 \pm 0.53$ \\
\hline & $6-10$ & $0.13 \pm 0.33$ & $0.28 \pm 0.26$ & $0.3 \pm 0.2$ & $0.8 \pm 0.42^{\mathrm{a}}$ & $0.95 \pm 0.48^{\mathrm{ab}}$ & $1.18 \pm 0.58^{b}$ \\
\hline & $4-10$ & $0.7 \pm 0.18^{a}$ & $0.8 \pm 0.21^{\mathrm{ab}}$ & $0.88 \pm 0.2^{b}$ & $1.3 \pm 0.38^{\mathrm{a}}$ & $1.42 \pm 0.4^{\mathrm{ab}}$ & $1.6 \pm 0.41^{b}$ \\
\hline
\end{tabular}

a,b Within-sex mean values on the same line and with no common superscript are significantly different $(P<0.05)$. 
Table 3 General linear model analysis of body weight ( $\mathrm{g}$ ) and $\mathrm{ADG}\left(\mathrm{g} /\right.$ day) of $\mathrm{F}_{2}$ males and females from divergent lines SS and $\mathrm{LL}$ at 4, 6 and 10 weeks of age.

\begin{tabular}{|c|c|c|c|c|c|c|c|}
\hline \multirow[b]{3}{*}{ Source } & \multirow[b]{3}{*}{ DF } & \multicolumn{3}{|c|}{ Body weight } & \multicolumn{3}{|l|}{ ADG } \\
\hline & & \multicolumn{3}{|l|}{$P$-value } & \multicolumn{3}{|l|}{$P$-value } \\
\hline & & 4 weeks & 6 weeks & 10 weeks & 4-6 weeks & 6-10 weeks & 4-10 weeks \\
\hline Dam (D) & 1 & 0.972 & 0.147 & 0.081 & 0.024 & 0.672 & 0.059 \\
\hline $\operatorname{Sex}(S)$ & 1 & 0.441 & 0.109 & $<0.0001 * * *$ & $0.0005^{* * *}$ & $<0.0001^{* * *}$ & $<0.0001 * * *$ \\
\hline Genotype (G) & 2 & 0.681 & 0.381 & $0.005^{* *}$ & 0.34 & $0.048^{*}$ & $0.011^{*}$ \\
\hline$D * S$ & 1 & 0.427 & 0.146 & 0.118 & 0.193 & 0.852 & 0.3 \\
\hline$D^{*} G$ & 2 & 0.274 & 0.918 & 0.585 & 0.232 & 0.729 & 0.523 \\
\hline$S^{*} \mathrm{G}$ & 2 & 0.687 & 0.915 & 0.411 & 0.799 & 0.508 & 0.606 \\
\hline$D * S * G$ & 2 & 0.664 & 0.999 & 0.718 & 0.517 & 0.631 & 0.598 \\
\hline
\end{tabular}

** * Significant difference at $0.1 \%$ level.

** Significant difference at $1 \%$ level.

* Significant difference at $5 \%$ level. lines during the long-term divergent selection experiment on body weight. Indeed, the association study in the $\mathrm{F}_{2}$ showed that IGF1R SNP was significantly associated with adult body weight and ADG. However, this association was not confirmed in random samples from all other Japanese quail lines. It is possible that the founder effect in the divergent selection experiment on body weight, combined with strong artificial selection for extreme small size in line SS, has led to much more drastic genetic changes in that line than selection for high body weight has caused in all the other lines and populations tested in the present work. At the same time, estimating the association from unstructured and rather small samples was certainly not as powerful as the analysis of variance of the $\mathrm{F}_{2}$ population from highly divergent body weight lines for detecting the association with the SNP genotype.

LL and SS lines used for constructing the $\mathrm{F}_{2}$ family had high inbreeding coefficients ( 0.73 for LL and 0.72 for SS) estimated from DNA fingerprint patterns (Mannen et al. 1993) and were fixed for alternate alleles on fourteen of 177 polymorphic AFLP bands (Piao et al. 2003). In addition, in birds, IGF1R is known to mediate two IGFs with different affinities. Therefore, the functional difference associated with the IGF1R SNP, together with the biological actions of other chromosomal SNPs with line specificity, may influence growth traits only in these selected lines. Thus, divergent lines SS and LL should be valuable resource populations for further studies on the identification of candidate genes for these growth and metabolism traits.

\section{References}

Amills M., Jimenez N., Villalba D., Tor M., Molina E., Cubilo D., Marcos C., Francesch A., Sanchez A. \& Estany J. (2003) Identification of three single nucleotide polymorphisms in the chicken insulin-like growth factor 1 and 2 genes and their associations with growth and feeding traits. Poultry Science 82, 1485-93.

Bennett A.K., Hester P.Y \& Spurlock D.E. (2006) Polymorphisms in vitamin $D$ receptor, osteopontin, insulin-like growth factor 1 and insulin, and their associations with bone, egg and growth traits in a layer-broiler cross in chickens. Animal Genetics 37, 283-6.

Mannen H., Tsuji S., Okamoto S., Maeda Y., Yamashita H., Mukai F. \& Goto N. (1993) DNA fingerprints of Japanese quail lines selected for high and low body weight. Japanese Poultry Science 30, 66-71.

Minvielle F., Hirigoyen E. \& Boulay M. (1999) Associated effects of the roux plumage color mutation on growth, carcass traits, egg production, and reproduction of Japanese quail. Poultry Science 78, 1479-84.

Minvielle F., Coville J.-L., Krupa A., Monvoisin J.-L., Maeda Y. \& Okamoto S. (2000) Genetic similarity and relationships of DNA fingerprints with performance and with heterosis in Japanese quail lines from two origins and under reciprocal recurrent or within-line selection for early egg production. Genetics Selection Evolution 32, 289-302.

Okamoto S., Kobayashi S. \& Matsuo T. (1989) Feed conversion to body weight gain and egg production in large and small Japanese quail lines selected for 6-week body weight. Japanese Poultry Science 26, 227-34.

Piao J., Shimogiri T., Maeda Y. \& Okamoto S. (2003) Analysis of genetic traits by AFLP in the Japanese quail lines selected for large and small body weight. Japanese Poultry Science 40, J13-20.

Yang Y.W., Robbins A.R., Nissley S.P. \& Rechler M.M. (1991) The chick embryo fibroblast cation-independent mannose 6-phosphate receptor is functional and immunologically related to the mammalian insulin-like growth factor-II (IGF-II)/man 6-P receptor but does not bind IGF-II. Endocrinology 128, 1177-89.

Zhao H., Rothschild M.F., Fernando R.L. \& Dekkers J.C.M. (2003) Tests of candidate genes in breed cross populations for QTL mapping in livestock. Mammalian Genome 14, 472-82.

\section{Supplementary material}

The following supplementary material is available for this article online from http://www.blackwell-synergy.com/doi/ full/10.1111/j.1365-2052.2007.01653.x

Table S1 Primers used in the study.

Please note: Blackwell Publishing is not responsible for the content or functionality of any supplementary materials supplied by the authors. 